International Journal of Current Advanced Research

ISSN: O: 2319-6475, ISSN: P: 2319 - 6505, Impact Factor: SJIF: 5.995

Available Online at www.journalijcar.org

Volume 6; Issue 5; May 2017; Page No. 3872-3875

DOI: http://dx.doi.org/10.24327/ijcar.2017.3875.0385

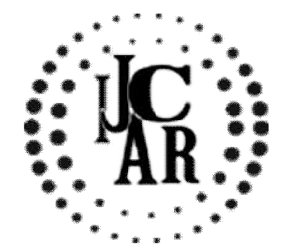

Research Article

\title{
ROLE OF ASSORTED INDUSTRIAL ASTHMAGENS: HYPOTHESES ON CONTEMPORARY APPROACH TO TARGET DISEASE KNOWLEDGE AND MEDICATION ADHERENCE AND TREAT OCCUPATION INDUCED ASTHMA
}

\author{
Muthukumar. A* and SundaraGanapathy .R
}

Faculty of Pharmacy, Karpagam University, Karpagam Academy of Higher Education, Coimbatore-21, Tamil Nadu, India

\begin{tabular}{l}
\hline A R T I C L E I N F O \\
\hline Article History: \\
Received $26^{\text {th }}$ February, 2017 \\
Received in revised form $2{ }^{\text {nd }}$ March, 2017 \\
Accepted $12^{\text {th }}$ April, 2017 \\
Published online $28^{\text {th }}$ May, 2017
\end{tabular}

\section{Key words:}

Industrial Asthmagen,

Patient Knowledge and Asthma

\begin{abstract}
A B S T R A C T
Patient education and drug adherence are most important factors that determine therapeutic outcomes; especially in patients are affliction from work induced chronic illness. Whatever the therapeutic efficacy of drug regimen, it cannot act unless otherwise the patients take it properly. Poor knowledge and medication adherence will assume importance as it seriously undermines the benefits of current treatment and imposes a significant pecuniary burden on individual patients and health care system. Patient should have knowledge in their etiology, usage of drug regarding occupation induced bronchial asthma. Estimation of patient knowledge and attitude is a crucial for the health improvements and wellbeing as well as preventing them from complications. In India, patients are scarceness of data concerning knowledge and drug devotion within the textile asthmagens induced occupational asthma. The current approach to expressed prevention and management of drug therapy against bronchial asthma but which had severe side effects and lesser therapeutic efficacy. Adverse drug reactions are produced by irrational treatment and rebelliousness. Based on current situation, these hypotheses exemplify to augment the efficacy of disease knowledge and drug obedience in a new way to treat employment induces asthma.
\end{abstract}

Copyright $(2017$ Muthukumar. A and SundaraGanapathy.R. This is an open access article distributed under the Creative Commons Attribution License, which permits unrestricted use, distribution, and reproduction in any medium, provided the original work is properly cited.

\section{INTRODUCTION}

Bronchial asthma is a major public health problem affecting large number of individuals of all ages. Globally, 100 to 150 million peoples are suffering from work related asthma and estimates indicate that, India has 20 to 28 million asthmatics and pervasiveness in between $10 \%$ to $15 \%$ patients affecting from occupational induced asthma [1-5]. Poor knowledge and drug adherence would be extent to which a patient's behavior coincides with health related advice and ability of the asthmatic patients to attend clinic appointments as per scheduled, take medicines as prescribed, and life style modification are recommendation for prevention and treatment asthma [6-10].

In recent document, the world health organization recognized lack of knowledge and poor adherence as a major problem in prevention and management of chronic disease including asthma and concluded that improving compliance would have more beneficial impact on health outcome that improving specific treatment for asthma. It is an acceptable fact for current medication that despite tremendous advances in diagnosis accuracy, if patients fail to recommended

*Corresponding author: Muthukumar. A

Faculty of Pharmacy, Karpagam University, Karpagam Academy of Higher Education, Coimbatore-21, Tamil medication that expenses and efforts involved are virtually wasted [11-15]. In recent years various approaches have been made to utilize the industrial asthmagens in pre clinical and clinical studies [16-40]. Nonetheless, in this clinical study we put forward to investigate the clinical survey on disease knowledge and drug adherence of asthmatic patients in Tirupur city and their therapeutic care.

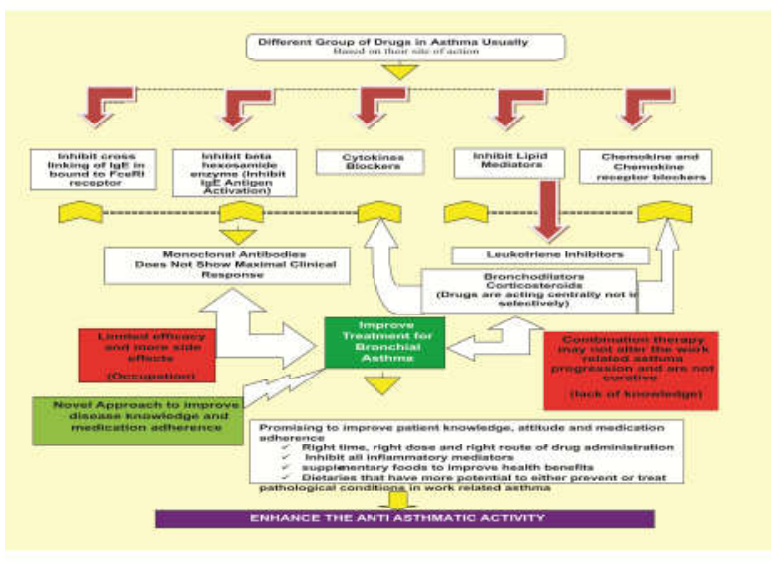

Figure 1 Role of Knowledge and Drug Adherence in Asthma 


\section{RESULTS AND DISCUSSION}

In Indians; poor knowledge is a major for health problem affecting a large number of individuals of all ages. bubonic plague disease resulting in increased morbidity and mortality. Assimilation of disease knowledge and drug devotion is given privilege to make use of it, as it reduce

Table 1 Role of Industrial Asthmagens Induced Bronchial Asthma

\begin{tabular}{|c|c|c|c|c|c|}
\hline S.No & $\begin{array}{c}\text { Industrial } \\
\text { asthmagens }\end{array}$ & Mechanism & Respiratory challenges & Commercial uses & Reference \\
\hline 1 & Carmine & $\begin{array}{l}\operatorname{IgE} \text { (antigen reaction) } \\
\text { Immunological mechanism }\end{array}$ & $\begin{array}{l}\text { Allergic alveolitis Anaphylactic } \\
\text { reactions Asthma }\end{array}$ & Cosmetic pharmaceutical dyeing & {$[16]$} \\
\hline 2 & Castor beans & Immunological mechanism & $\begin{array}{l}\text { Rhinitis Conjunctivitis } \\
\text { Wheezing Asthma }\end{array}$ & $\begin{array}{l}\text { Plastics Hydraulic fluids } \\
\text { Textile finishing materials }\end{array}$ & {$[17]$} \\
\hline 3 & Chloramine-T & Immunological mechanism & $\begin{array}{l}\text { Asthma Anaphylactic reactions } \\
\text { Bronchial and Nasal challenge }\end{array}$ & $\begin{array}{c}\text { Anti viral } \\
\text { Bactericidal }\end{array}$ & {$[18]$} \\
\hline 4 & $\begin{array}{l}\text { Chloroplatinate } \\
\text { salts }\end{array}$ & Immunological mechanism & $\begin{array}{l}\text { Rhinitis Conjunctivitis } \\
\text { Wheezing Asthma }\end{array}$ & $\begin{array}{l}\text { Refining of Platinum metal, } \\
\text { ammonium, sodium and potassium }\end{array}$ & [19] \\
\hline 5 & $\begin{array}{l}\text { Cow urine and } \\
\text { epithelium }\end{array}$ & $\begin{array}{l}\text { IgG and IgE antibodies to bovine } \\
\text { urine and epithelium }\end{array}$ & $\begin{array}{c}\text { Asthma Reduction in peak expiratory flow } \\
\text { Bronchial and Nasal challenge }\end{array}$ & Agriculture & {$[20]$} \\
\hline 6 & Crustacean protein & $\begin{array}{l}\text { Bronchial challenge and lung } \\
\text { function tests Immediate skin } \\
\text { reactivity Increased serum levels of } \\
\text { specific IgE }\end{array}$ & $\begin{array}{l}\text { Wheeze Cough } \\
\text { Breathlessness }\end{array}$ & $\begin{array}{l}\text { Prawn } \\
\text { Crab }\end{array}$ & {$[21]$} \\
\hline 7 & Diazonium salts & $\begin{array}{l}\text { Immunological mechanism and } \\
\text { irritant reaction }\end{array}$ & $\begin{array}{l}\text { Asthmatic response } \\
\text { (wheeze, chest tightness) }\end{array}$ & $\begin{array}{l}\text { Dyes Polymer production } \\
\text { Photocopier }\end{array}$ & {$[22]$} \\
\hline 8 & Ehtylenediamine & $\begin{array}{l}\text { Immunological mechanism and } \\
\text { irritant reaction }\end{array}$ & $\begin{array}{c}\text { Asthmatic response } \\
\text { (wheeze, chest tightness) }\end{array}$ & $\begin{array}{l}\text { Urea Resins } \\
\text { Fatty bisamides }\end{array}$ & [23] \\
\hline 9 & Glutaraldehyde & Irritant reactions & Asthmatic Reponses & $\begin{array}{c}\text { Disinfectant Cold sterility } \\
\text { Medical and surgical instruments }\end{array}$ & {$[24]$} \\
\hline 10 & Hardwood dusts & Decrease in forced expiratory volume & $\begin{array}{l}\text { Rhinitis Conjunctivitis } \\
\text { Wheezing Asthma }\end{array}$ & Interior for house & {$[25]$} \\
\hline 11 & Isocyanates & Symptoms of bronchial asthma & $\begin{array}{l}\text { Bronchitis COPD Urticaria } \\
\text { Allergic alveolitis Asthma }\end{array}$ & $\begin{array}{l}\text { Auto mobile painting } \\
\text { Plastics coating Adhesives }\end{array}$ & {$[26]$} \\
\hline 12 & Papain & $\begin{array}{l}\text { Immunological mechanism } \\
\text { Symptoms of bronchial asthma }\end{array}$ & $\begin{array}{c}\text { Asthma Bronchitis Urticaria } \\
\text { Allergic alveolitis }\end{array}$ & $\begin{array}{l}\text { Wool, silk Production } \\
\text { Cosmetic }\end{array}$ & {$[27]$} \\
\hline 13 & Phthalic anhydride & $\begin{array}{l}\text { Increased serum levels of specific } \\
\operatorname{IgE} \text { or } \operatorname{IgE}\end{array}$ & Phthalic anhydride Exposure induced asthma & $\begin{array}{l}\text { Plasticizers } \\
\text { Resins Dyes }\end{array}$ & {$[28]$} \\
\hline 14 & Piperazine & $\begin{array}{l}\text { Respiratory sensitizer } \\
\text { Immunological basis for the asthma }\end{array}$ & $\begin{array}{c}\text { Developed rhinitis } \\
\text { Progressing to asthma attack }\end{array}$ & Anti-helminthic agent & [29] \\
\hline 15 & $\begin{array}{l}\text { Reactive dyes } \\
\text { contain three } \\
\text { moieties } \\
\text { Anthraquinone }\end{array}$ & $\begin{array}{l}\text { Specific immunoglobulin ( } \mathrm{IgE}) \text { in } \\
\text { particular showing a good correlation } \\
\text { with bronchial challenge }\end{array}$ & $\begin{array}{l}\text { Exposed to reactive dyes developed work } \\
\text { related rhinitis Then asthma }\end{array}$ & Textile and dying industries & {$[30]$} \\
\hline 16 & Colophony & $\begin{array}{l}\text { Respiratory sensitizer } \\
\text { Immunological basis for the asthma }\end{array}$ & $\begin{array}{c}\text { Rhinitis Conjunctivitis Wheezing } \\
\text { Asthma }\end{array}$ & Electronics factory & {$[31]$} \\
\hline 17 & Softwood dusts & $\begin{array}{l}\text { Increased serum levels of specific } \\
\qquad \operatorname{IgE} \text { or } \operatorname{IgE}\end{array}$ & $\begin{array}{c}\text { Developed rhinitis } \\
\text { Progressing to asthma attack }\end{array}$ & Interior for house & {$[32]$} \\
\hline 18 & Spiramycin & Symptoms of bronchial asthma & Occupational rhino conjunctivitis & Macrolide antibiotic & {$[33]$} \\
\hline 19 & Coffee bean dust & $\begin{array}{l}\text { Exposed to an allergen and } \\
\text { respiratory sensitizer }\end{array}$ & $\begin{array}{l}\text { Sneezing Nasal itching } \\
\text { wheezing Asthma }\end{array}$ & Coffee processing industry & {$[34]$} \\
\hline 20 & Egg yolk & $\begin{array}{l}\text { Immunoglobin cause food induced } \\
\text { allergies }\end{array}$ & Asthma Rhino Conjunctivitis & Baker products & {$[35]$} \\
\hline 21 & Fish proteins & $\begin{array}{l}\text { Hyper sensitivity showed allergic } \\
\text { reactions (wheezing and Urticaria) }\end{array}$ & Wheezing or chest tightness after ingesting fish & Food products & {$[36]$} \\
\hline 22 & Henna & $\begin{array}{l}\text { Henna dye - associated asthma by } \\
\text { immunological response }\end{array}$ & Wheeze and breathlessness & Cosmetic preparation & {$[37]$} \\
\hline 23 & Opiates & $\begin{array}{l}\text { Plausible mechanism for asthma } \\
\text { induction }\end{array}$ & $\begin{array}{l}\text { Comprised cough } \\
\text { Dyspnoea Rhinitis }\end{array}$ & Pharmaceutical uses & {$[38]$} \\
\hline 24 & $\begin{array}{l}\text { Alpha amylase } \\
\text { enzymes }\end{array}$ & $\begin{array}{l}\text { Occupational broncho asthma which } \\
\text { is mediated by an immunological } \\
\text { mechanism involving }\end{array}$ & $\begin{array}{l}\text { Asthma } \\
\text { rhino conjunctivitis }\end{array}$ & $\begin{array}{c}\text { Bacterial alpha amylase animal feeds } \\
\text { and detergents } \\
\text { Bread baking }\end{array}$ & {$[39]$} \\
\hline 25 & Cephalosporin's & Immediate falls in FEV & $\begin{array}{l}\text { Rhinitis Asthma type } \\
\text { Symptoms during the night time in home }\end{array}$ & Semi synthetic antibiotics & {$[40]$} \\
\hline
\end{tabular}

Being a chronic condition of disease, management of bronchial asthma requires proper medical care. The term drug adherence means, "sticking to a plan" for perceived benefit. Strategies that may lead to elimination or control of asthma triggers are important in the management of asthma and should be incorporated into patient education. Narrative approach to target industrial asthmagens, prevention and treatment bronchial asthma with appropriate awareness and medication devotion system to enhance the anti asthmatic activity on patients suffered from asthma has been discussed in this critique. Occupational asthma is the world wide spread
44]. Lack of knowledge and medication adherence with prescribed regimen may result in to misconceptions on disease management, especially in patients suffering from work related asthma. Drug adherence is determining therapeutic efficacy for chronic illness. Poor knowledge and adherence leads to reduced treatment benefits and can obscure the physician's assessment of therapeutic effectiveness. Almost all the patients should not have appropriate disease knowledge, attitude and perception for occupation induced bronchial asthma. Improving the patient knowledge and awareness on work related asthma reporting among the textile 
worker should be made compulsory apart from their curriculum [45-48]. The current approach of the prevention and management of asthma includes the addition of drugs in a stepwise fashion on the severity of symptoms and stronger asthmatic agents are more prone to have severe side effects [49-53]. The limited therapeutic efficacy and adverse effects with conventional treatment has leads to the introduction of asthma knowledge and drug adherence.

\section{CONCLUSION}

In this article, we proposed a new approach to target disease knowledge and drug adherence with enhanced anti asthmatic activity from industrial asthmagens. The proposed medication knowledge is play vital role to reduce the adverse drug reaction and avoiding the multiple drug regimens. The target on asthma sensitizer and patient education is expected to better result for treatment of occupation induced bronchial asthma.

\section{References}

1. Gajanan S.Gaude. Factors affecting non-adherence in bronchial asthma and impact of health education. Indian j allergy asthma immunol.2011; 25(1):1-8.

2. Ajay R Fugate,A M Kadamand M S Ganachari. Prospective study of medication adherence pattern in chronic obstructive pulmonary disease and asthma patients in tertiary care teaching hospital. Indian journal of pharmacy practice.2015; 8(2):78-83.

3. Paramesh H. Epidemiology of asthma in India. Indian J Pediatr 2002; 69:309-312.

4. Prem Prakash Gupta and K. B.Gupta. Awareness about the disease in asthma patient receiving treatment from physicians at different places. The Indian journal of chest diseases and allied sciences. 2001; 58(2):1-6.

5. Tettersell M.J. Asthma patient's knowledge in relation to compliance with drug therapy. Journal of advadnced nursing. 1993; 18:103-113.

6. Wigal JK, Stout C, Brandon M. The knowledge, attitude and self efficacy asthma questionnaire. Chest.1993; 104(4):1144-1148.

7. Mahendra Kumar BJ, Jose J, Kumarswamy M, Naveen MR, Assessing the knowledge, attitude and medication adherence among asthma patients in a rural population. Asian J Pharm Clin res.2011; 4(1):93-97.

8. Rand C.S, wise R.A, Johns Hopkins. Measuring adherence to asthma medication regimens asthma and allergy center. J medline.2012; 12(3):7.

9. Meszaros A.F, Orosz M, Magyar P, Mesko A, Vincze Z. Evaluation of asthma knowledge and quality of life in Hungarian asthmatics. Allergy 2003; 58(7):624-628.

10. Hope NH, Shaunta M R, Franks A S, Heidel E. Impact of an educational intervention on steroid prescribing and dosing effect on patient outcomes in COPD exacerbations. Pharmacy practice 2010; 8(3):16-166.

11. Franks T.J, Burton D.L, Simpson M.D. Patient medication knowledge and adherence to asthma pharmacotherapy: a pilot study in rural Australia. Therapeutics and Clinical Risk Management.2005; 1 (1):33-38.

12. Graham Barr R, Somers S.C, Speizer F.E, Camargo A.C. Patient factors with medication adherence among older women with asthma. Arch intern med.2012; 162:1761-1768.

13. Anjan Kumar D.S, Adequ R, Parthasarathi G, Mahesh P.A. Impact of community pharmacist provided patient education in asthma patients on treatment outcomes-a study. Indian J Pharm Educ Res 2009; 43(2):125-33.

14. Burge P.S, O Brien I.M, Harries M.G and Pepys J. occupational asthma due to inhaled carmine. Clin Allergy. 1979; 9:185-189.

15. Lenz D, Pelletier A, Pauli G. occupational asthma from cochineal carmine. Rev fr mal resp.1983; 11:487-488.

16. Burge PS, O'Brien IM, Harries MG and Pepys J. Occupational asthma due to inhaled carmine Clin Allergy. 1979; 9:185-189.

17. Topping MD, Henderson RTS, Luczynska CM and Woodmass A.Castor bean allergy among workers in the felt industry Allergy. 1982; 37: 603-608.

18. Evans JC, Jackson SK and Rowlands CC.Covalent binding of human serum albumin and ovalbumin by chloramine- $\mathrm{T}$ and chemical modification of the proteins AnalytChimActa. 1986; 186:319-323.

19. Wass U, Belin L and Eriksson NE.Immunological specificity of chloramine-T induced IgE antibodies in serum from a sensitized worker. ClinExp Allergy. 1989; 19: 463-471.

20. Virtanen T, Vilhunen P, Husman K and Mantyjarvi R.Sensitization of dairy farmers to bovine antigens and effects of exposure on specific IgG and IgE titersInt Arch Allergy ApplImmunol. 1988; 87: 171-177.

21. Dugue P, Lachaussee R and Garcia G .Prawn-induced occupational asthma: a case history involving cross digestive and respiratory allergy Rev FrAllergol. 1988; 28:17-18.

22. Luczynska CM, Hutchcroft BJ, Harrison MA.Occupational asthma and specific $\operatorname{IgE}$ to a diazonium salt intermediate used in the polymer industry J AllergClinImmunol. 1990; 85: 1076-1082.

23. Lam S and Chan-Yeung M.Ethylenediamine-induced asthma Am Rev Resp Dis. 1980; 121:151-155.

24. Gannon PFG, Bright P, Campbell M.Occupational asthma due to glutaraldehyde and formaldehyde in endoscopy and X-ray departments Thorax. 1995; 50:156-159.

25. Carosso A, Ruffino $\mathrm{C}$ and Bugiani M.Respiratory diseases in woodworkers $\mathrm{Br} J$ Ind Med. 1987; 44:5356.

26. Kennedy AL and Brown WE.Isocyanates and lung disease: experimental approaches and molecular mechanisms Occup Med. 1992; 7:301-329.

27. Novey HS, Keenan WJ, Fairshter RD.Pulmonary disease in workers exposed to papain: clinicophysiological and immunological studies Clin Allergy. 1980; 10:721-731.

28. Nielson J, Welinder H, Schutz A and Skerfving S.Specific serum antibodies against phthalic anhydride in occupationally exposed subjects $J$ Allergy ClinImmunol. 1988; 82: 126-133.

29. Welinder H, Hagmar L and Gustavsson C. IgE antibodies against piperazine and $\mathrm{N}$-methyl piperazine in two asthmatic subjects Int Arch Allergy ApplImmunol. 1986; 79: 259-262. 
30. Romano C, Sulotto F, Pavan I.A new case of occupational asthma from reactive dyes with severe anaphylactic response to the specific challenge $\mathrm{Am} \mathrm{J}$ Ind Med. 1992; 21: 209-216.

31. Burge PS, Edge G, Hawkins R. Occupational asthma in a factory making flux-cored solder containing colophony Thorax. 1981; 36: 828-834.

32. Chan-Yeung $M$ and Abboud R. Occupational asthma due to Californian redwood (Sequoia sempervirens) dusts Am Rev Resp Dis. 1976; 114:1027-1031.

33. Malo JL and Cartier A.Occupational asthma in workers of a pharmaceutical company processing spiramycin Thorax. 1988; 43: 371-377.

34. Uragoda CG.Acute symptoms in coffee workers. $J$ Trop Med Hyg. 1988; 91:169-172.

35. Fremont S, Kanny G, Nicholas JP and Moneret-Vautrin DA.Prevalence of lysozyme sensitisation in an eggallergic population. Allergy. 1997; 52:224-228.

36. Helbling A, McCants ML, Musmand JJ.Immuno pathogenesis of fish allergy: identification of fishallergic adults by skin test and radioallergosorbent test. Ann Allergy Asthma Immunol. 1996; 77: 48-54.

37. Scibilia J, Galdi E, Biscaldi G and Moscato G.Occupational asthma caused by black henna Allergy. 1997; 52: 231-232.

38. Ulinski S, Palczynski C and Gorski P. Occupational rhinitis and bronchial asthma due to morphine: evidence from inhalational and nasal challenges Allergy. 1996; 51: 914-918.

39. Aiken TC, Ward R, Peel ET and Hendrick DJ.Occupational asthma due to porcine pancreatic amylase Occup Environ Med. 1997; 54:762 - 764.

40. Stenton SC, Dennis JH and Hendrick DJ.Occupational asthma due to ceftazidime Eur J Respir Dis. 1995; 8:1421-1423.

41. Chan-Yeung M, Malo I. Etiological agents- in occupational asthma. EurRespr J.1994; 7:346-71.

42. Juniper EF, Guyatt GH, Epstein RS, Epstein RS, Ferrie PJ, Jaeschke R, et al. Evaluation of impairment of health related quality of life in asthma: development of a questionnaire for use in clinical trials. Thorax. 1992; 47(2):76-83.

43. Christiani, D.C., Eisen, E.A., Wegman, D.H.,Ye, T.T., Gong, Z.C., Lu, P.L. and Dai, H.L.Respiratory Disease in Cotton Textile Workers in the People's Republic of China.II.Pulmonary Function Results. Scand $J$ Work Environ Health. 1986; 12(1):46-50.
44. Nathan RA, Sorkness CA, Kosinski M, Schatz M, Li JT, Marcus P, et al. Development of the asthma control test: a survey for assessing asthma control. J Allergy Clin Immunol 2004; 113(1): 59-65.

45. Puhan MA, Gaspoz JM, Bridevaux PO, Schindler C, Ackermann-Liebrich U, Rochat $\mathrm{T}$, et al. Comparing a disease-specific and a generic health-related quality of life instrument in subjects with asthma from the general population Health Qual Life Outcomes. 2008; 6(15):1-11.

46. Carranza Rosenzweig JR, Edwards L, Lincourt W, Dorinsky P, ZuWallack RL. The relationship between health-related quality of life, lung function and daily symptoms in patients with persistent asthma. Respir Med 2004; 98(12):1157-65.

47. Mohammed Maazuddin, Mohd. Nasir Mohiuddin, Mohd. Javeedullah, Sana Afreen. Prescription Monitoring of drugs used for asthma and COPD: A retrospective, before-after study. Int. J. Pharm. Med. Res. 2014; 2(2):43-48.

48. Mohammed Maazuddin, Mohd. Nasir Mohiuddin, Mohd. Javeedullah, Sana Afreen. Prescription Monitoring of drugs used for asthma and COPD: A retrospective, before-after study. Int. J. Pharm. Med. Res. 2014; 2(2):43-48.

49. Chetna A. Shamkuwar1, NaliniKumari, Sushant H. Meshram, Ganesh N. Dakhale4 And Vijay M. Motghare Evaluation of knowledge, attitude and medication adherence among asthmatics outpatients in teaching hospital-a questionnaire based study $j$ young pharm, 2016; 8(1): 39-43.

50. Asthma care quick reference, diagnosing and managing asthma. U.S. Department of health and human services.2011; 12(1):1-12.

51. Pocket guide for asthma management and prevention. Global Initiative for Asthma.2015; 1(1): 1-27.

52. Rajinder Singh Bedi. Patient education programme for asthmatics: Indian Prospective. The Indian Journal of Chest Diseases and Allied Sciences.2007; 49:93-98.

53. Mahendra Kumar Bj, Jose J, Kumarswamy M, Naveen Mr. assessing the knowledge, attitude and medication adherence among asthma patients in a rural population. Asian j pharm clin res. 2011; 4(1): 93-7.

\section{How to cite this article:}

Muthukumar. A and SundaraGanapathy .R (2017) ' Role Of Assorted Industrial Asthmagens: Hypotheses On Contemporary Approach To Target Disease Knowledge And Medication Adherence And Treat Occupation Induced Asthma', International Journal of Current Advanced Research, 06(05), pp. 3872-3875.

DOI: http://dx.doi.org/10.24327/ijcar.2017.3875.0385 